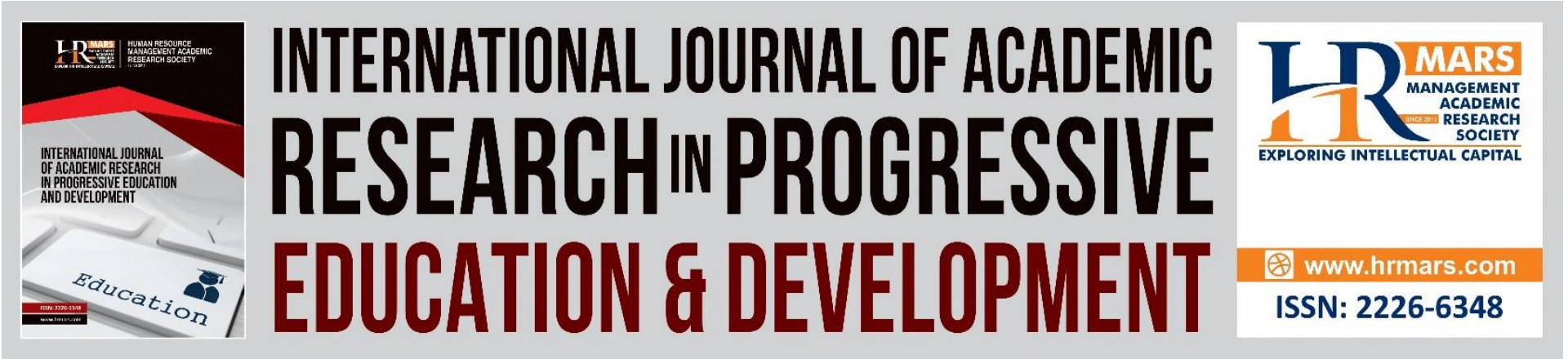

\title{
Improving Reading Skills of Tamil Words with The Use of Augmented Reality (AR)
}

Ganesh Mukayah, Rosseni Din, Nabilah Othman

To Link this Article: http://dx.doi.org/10.6007/IJARPED/v11-i1/12285

DOI:10.6007/IJARPED/v11-i1/12285

Received: 11 November 2021, Revised: 15 December 2021, Accepted: 30 December 2021

Published Online: 21 January 2022

In-Text Citation: (Mukayah et al., 2022)

To Cite this Article: Mukayah, G., Din, R., \& Othman, N. (2022). Improving Reading Skills of Tamil Words with The Use of Augmented Reality (AR). International Journal of Academic Research in Progressive Education and Development, 11(1), 979-993.

Copyright: (C) 2022 The Author(s)

Published by Human Resource Management Academic Research Society (www.hrmars.com)

This article is published under the Creative Commons Attribution (CC BY 4.0) license. Anyone may reproduce, distribute, translate and create derivative works of this article (for both commercial and non-commercial purposes), subject to full attribution to the original publication and authors. The full terms of this license may be seen

at: http://creativecommons.org/licences/by/4.0/legalcode

Vol. 11(1) 2022, Pg. 979 - 993

http://hrmars.com/index.php/pages/detail/IJARPED

JOURNAL HOMEPAGE

Full Terms \& Conditions of access and use can be found at http://hrmars.com/index.php/pages/detail/publication-ethics 


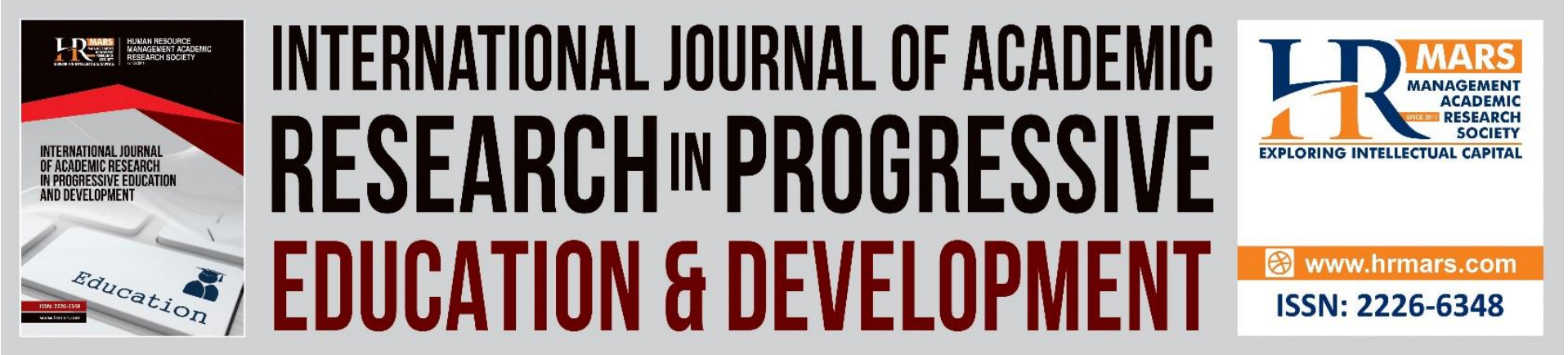

\title{
Improving Reading Skills of Tamil Words with The Use of Augmented Reality (AR)
}

\author{
Ganesh Mukayah \\ Faculty of Education, University Kebangsaan Malaysia, 43600 UKM Bangi, Selangor, \\ MALAYSIA \\ Email: p105779@siswa.ukm.edu.my

\begin{abstract}
Rosseni Din (Corresponding Author)
Center for STEM Enculturation Research, Faculty of Education, University Kebangsaan Malaysia, 43600 UKM Bangi, Selangor, MALAYSIA

Email: rosseni@ukm.edu.my

Nabilah Othman

Faculty of Education, University Kebangsaan Malaysia, 43600 UKM Bangi, Selangor, MALAYSIA
\end{abstract} \\ Email: cik.nabilah001@gmail.com
}

\begin{abstract}
This study was conducted to improve Tamil reading skills using augmented reality (AR) among Year 4 students. Accordingly, an integrated Tamil language e-module with Augmented Reality (AuRa-BT), based on the Universal Design for Agile Development model and minimalist theory was designed and developed. Before and after the e-module implementation, a survey was conducted using questionnaires and checklists as research tools. Questionnaires, and checklists were used as tools to verify of content and usability of AURa-BT module. Respondents of the study are 50 students and 8 teachers. Descriptive methods were used to analyze the data obtained. The overall study results show that the use of AURa-BT Module combined with Augmented Reality Technology can improve the reading skills of Tamil words among Year 4 students. The use of AuRa-BT shows an improvement in Tamil reading skills among Year 4 students. In general, this study shows that the use of augmented reality (AR) technology can easily attract students and teachers to improve Tamil word reading skills.

Keywords: Technology, Augmented Reality (AR), Tamil Language, AURa-BT
\end{abstract}

\section{Introduction}

In the era of globalization, information technology and communication had affected the world towards modernization. Humans can master, recognize, and control almost everything education at the fingertips using ICT. The push of ICT development in the field of education continues to affect society positively. Utilizing ICT is a strategy to increase the level of 
education in Malaysia. The 7th shift of the Malaysia Education Development Plan 2013-2025 states that the use of ICT can improve quality learning in Malaysia. According to Yusof \& Tahir (2017), the use of ICT in the learning process is an important parallel to the development of the modern world of education today. Integration of technology makes the learning process more interesting and productive. Techniques using technology to intertwine voice, sound, picture, video, and text make the learning process more interesting and fun. Students today are more interested to learn interactively. Jenal (2017) stated that learning in interactively can attract students' interest, attention, and arouse positive curiosity. In addition, the use of ICT with a combined elements of technology such as audio, visuals, graphics and animation can increase quality teaching and learning. Teaching with ICT-based methods and media can help educators. At the same time, it can attract students to master skills related to reading, writing, and counting. Education system is important to wake up the society and country towards a better direction. In Malaysia, the use of Tamil is widespread. For example, it is an intermediary language at the National Primary School, an additional subject in Lower Secondary school and in some universities in Malaysia. Thus, reading Tamil is essential as a source of knowledge to include various kind of reading material (Razak, 2019).

According to Karim (1989), reading is a process of understanding and constructing understanding. Reading means to change writing to speech. It moves text to voice and captures meaning and understanding what is read. In addition, reading skills is a basic need for students in Primary School Standard Curriculum (KSSR). Use of ICT in the delivery of education can help the process of teaching and facilitation. Implementation of 21st Century learning demands every teacher to act more creatively and innovatively (Abdul Mutalib, 2017). According to Saeed \& Zyngier (2012), researchers in the area support the importance of motivation and engagement in the learning process. Thus, we can conclude that low interest in reading will affect the academic achievement of a student. Augmented Reality $(A R)$ is a new technology using a virtual environment that helps students look at the real world through a computer screen or mobile phone. Using technology such as this can enhance the learning process even faster, easier, and more fun for students. The use of AR in teaching and facilitation sessions can give new dimensions in the world of education because of its flexible characteristics that allow accessibility anytime and anywhere with coverage of internet lines (Vargavan \& Yunus, 2021). In addition, more students are willing and interested to accept lessons through the exposure and application of AR in teaching and learning. When educators apply AR in teaching and facilitation sessions, students can also bring out their critical and creative thoughts.

AR was created by Tom Caudell in 1990. It translates integration of virtual images in the real world. It is an emergence of continuous technology which offer opportunities for new and exciting teaching and learning media for educator (Achterbosch, 2007). Educators need to accept new technology in preparation for more interactive media enabling environment to attract student interest (Muller, 2012). AR involves virtual content, interaction, real authentic environment, digital storytelling and capable of giving experience for students to learn something new beyond imagination. AR is not a singular application but uses computer, mobile phone, webcam, or head-mounted display to support its function. The teaching and learning provided by AR technology is increasing to make learning process more active, interesting, motivating, and meaningful to students. According to Abd Majid (2018), AR gives immersive experience and has the potential to facilitate complex learning. According to Ganti \& Lubis (2018), AR technology can attract attention and stimulate interest children 
in the process of learning, facilitate understanding content learning, save memory in the long term, and friendly users.

Observation in the early research shows that students, especially in Tamil language subject, have weaknesses in reading and spelling words in Tamil. Findings also showed few pupils interested in reading Tamil because students do not favor traditional methods such as the Chalk and Talk method. Furthermore, the observation shows that students do not take the initiative to read independently but only read in school. This is because students feel that reading is a tedious activity. Thus, reading as a habit at home is greatly reduced among students. Reading skills is important to increase mastery in basic Tamil. It allows students to use the language learned in communication orally and written. This research aims to identify if reading skills in Tamil year 4 students can be improved with the use of Augmented Reality (AR). Thus, the objective and the research questions for the study were formulated as the following:

Objective

I. To identify the level of Tamil reading skill of Year 4 students before using AuRa-BT module?

II. To identify the level of Tamil reading skill of Year 4 students after using AuRa-BT module?

III. To identify student's perception about usefulness of AuRa-BT module?

Research Questions

I. What is the level of Tamil reading skill of Year 4 students before using AuRa-BT module?

II. What is the level of Tamil reading skill of Year 4 students after using AuRa-BT module?

III. What is student's perception about usefulness of AuRa-BT module?

\section{Methodology}

The agile version (Din, 2016; Din, 2020) of the integrated model for the instructional design, development, and modeling of a personalized learning environment in education, namely the UDin model, is presented in Figure 1 (Din, 2020). The UDin model, a 20-year transformation model of the design, development, and modeling of a learning system, added the taken-forgranted Learning Outcome component. This was aligned with the Assessment component, and both were placed in the center as the innermost part of the model labeled Learning Outcome and Assessment (Din, 2016; Din, 2020). The model emphasizes continuous assessment. The rubrics are mainly used as assessment tools. The assessment methods ranging from gamification, reflection, visual, video and technology-mediated communication to fieldwork (Din, 2016; Din, 2020). Din's previous work discusses the assessment method and tools in detail; this encompasses studies by Din et al (2017a, 2017b). Conventional quizzes transformed into interactive online quizzes are also used as formative evaluation alternatives in online modules. Some courses also retain the pen-and-pencil test, primarily for final summative evaluation. The universal input attributes are learning theories, learning strategy, pedagogy, content, and values. 


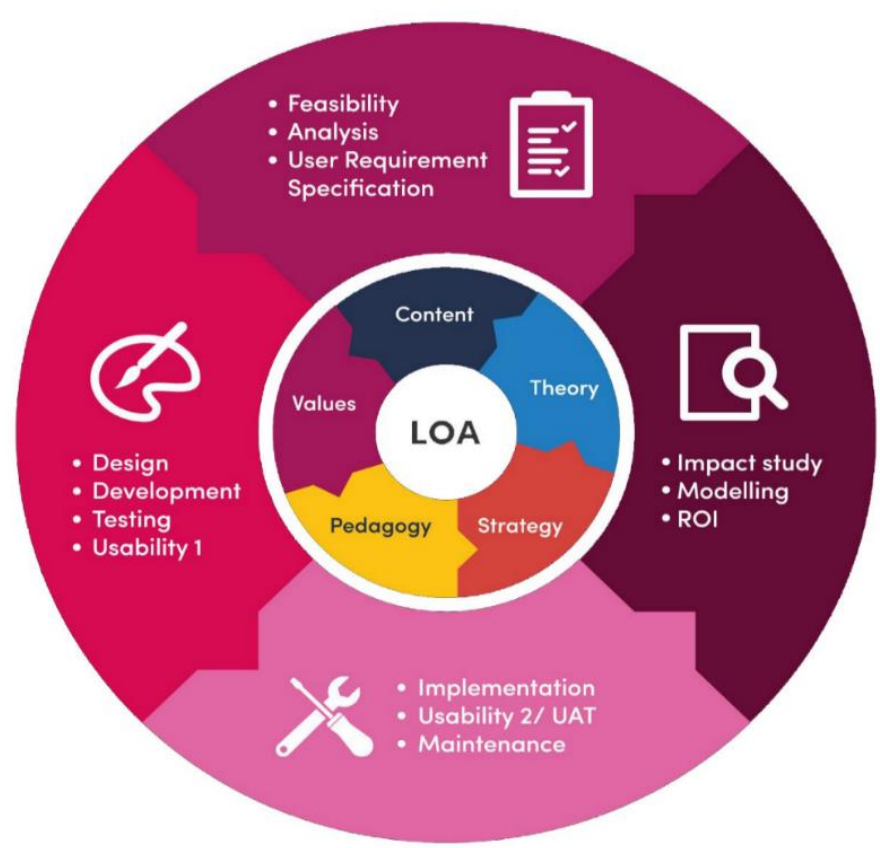

Figure 1: UDin model or the Rengkas Model (Ishak et al., 2021; Din, 2020; Din, 2016)

According to Azuma (1997; 2001), AR has three main characteristics, combining real and virtual worlds, having real-time interaction with users, and interactive by sowing reality with two dimensional and three-dimensional animation. AR allows users to see the real thing without being completely in the same environment. According to Chehimi et al (2007), learning with the traditional method needs to be fixed to ensure students get more quality education.

Changes in the education system will change learning based on memory to more motivated and creative knowledge (Nischelwitzer, 2007). AR can give students motivation with intuitive function and friendly user interaction for better understanding in teaching and learning (Chen, 2006). Furthermore, AR is in a virtual environment with a physically ready environment (Jantakoon et al., 2019). Through AR technology, virtual objects can be seen real in the background. In short, AR technology brings virtual imagination to the real world. Physical experience, virtual content, storytelling, and user imagination is learning experience shaped by ideal entertainment available in reality mix and match (Stapleton et al., 1996). Motivation and focus to the goodness of learning with technology (Dunser, 2007), in addition to the ability to build understanding from the dynamic 3D process (Winn et al., 2002). AR use is widespread, particularly in the area of education. Nowadays, AR applications can be combined to improve the curriculum standards used. For example, text, graphics, VideoVideo, and audio can be coated with students' real-time environment time to learn better. Moreover, AR, can produce additional information for students displayed in multimedia. According to Yusof et al (2019), AR creates a profound experience by expanding the virtual environment, allowing students to describe learning content to understand associated learning topics better. Therefore, AR is a new technology that can materialize the integration of computer and digital world education with the real world in real-time. According to Siltanen (2012), AR is one area of computer science research that combines real-world and digital data. With $A R$, children can interact with virtual objects covering the real environment for mixed and real experience (Lam et al., 2020). In line with the development of Malaysia towards revolution industry 4.0, this study focuses on technology in education with the use 
of AR technology to increase Tamil reading skills amongYear 4 students with the help of ROAR application.

The respondent for this research was chosen from students and teachers who teach and learn Tamil Year 4 curriculum. The research module was developed with the minimalist concept, which allows students to explore the content of the AuRa-BT module on the website with the integration of the ROAR application. Therefore, students feel more fun reading with integrated text, graphics, video and audio in real-time. In addition to that, the minimalist theory allows students to begin learning and activities faster through the module. The minimalism concept is also absorbed in the module interface by considering the size and colour of the font contrast in the module background, font, diagrams, AR graphics, and video. According to Zaki (2014), the use of various media makes students feel fun which subsequently allows behavioural change resulting in learning to happen easily.

AuRa-BT encourages students to read intensively with fun. The name AuRa-BT in more detail is: 'Au' means Augmented while 'Ra' means reality, 'BT' means the Tamil Language. AuRa-BT consists of a combined AR module with interactive words delivered and presented via the WordPress platform using ROAR applications. The student assessment part is performed using QuizWhizzer. Students will first access the WordPress page and observe interactive Tamil words on this website. The module contains information to be followed in detail, such as pictures about associated letters, syllables, and words to help reading. Next, the student will scan pictures available in the module using a smartphone and learn how to pronounce the words. Then, they will listen to audio and Video through the ROAR application and finally read the words. AuRa-BT applies advanced elements to cultivate skills to read words that involve deep syllables. This is to ensure students can master reading in the allotted time. After studying how to pronounce such words, students will be assessed through the Quiz Whizzer game. The game aims to evaluate respondents' achievement.

Figure 2 shows the developed AuRa-BT on WordPress integrated with the ROAR application. WordPress was selected as the primary communication tool because it is flexible and friendly. la allows flexible and changeable theme displays which are user-friendly. In addition, this portal also incorporates Web 2.0- enabled applications like AuRa-BT and makes words, videos, and questions to be more attractive and flexible. The ROAR application is an AR application developed in 2011. Its founder is Oksana Sokolovsky. ROAR is an application that gives opportunities to explore details and features of text or visual images just by scanning. Combined AuRa-BT Modules (Figure 3, Figure 4 and Figure 5) by wordpress.com as the main platform allows text, video, and audio integration in Tamil for each word. Video will appear after pictures of words are scanned using a smartphone with ROAR mobile software. The video can be exactly where we are. This feature helps students to read the words in a fun way. At the same time, it attracts students to surf websites created by researchers to continue learning how to read. In addition, the site also has various reading materials including comics and storybooks that students can read. 
INTERNATIONAL JOURNAL OF ACADEMIC RESEARCH IN PROGRESSIVE EDUCATION AND DEVELOPMENT

Vol. 11, No. 1, 2022, E-ISSN: 2226-6348 @ 2022 HRMARS

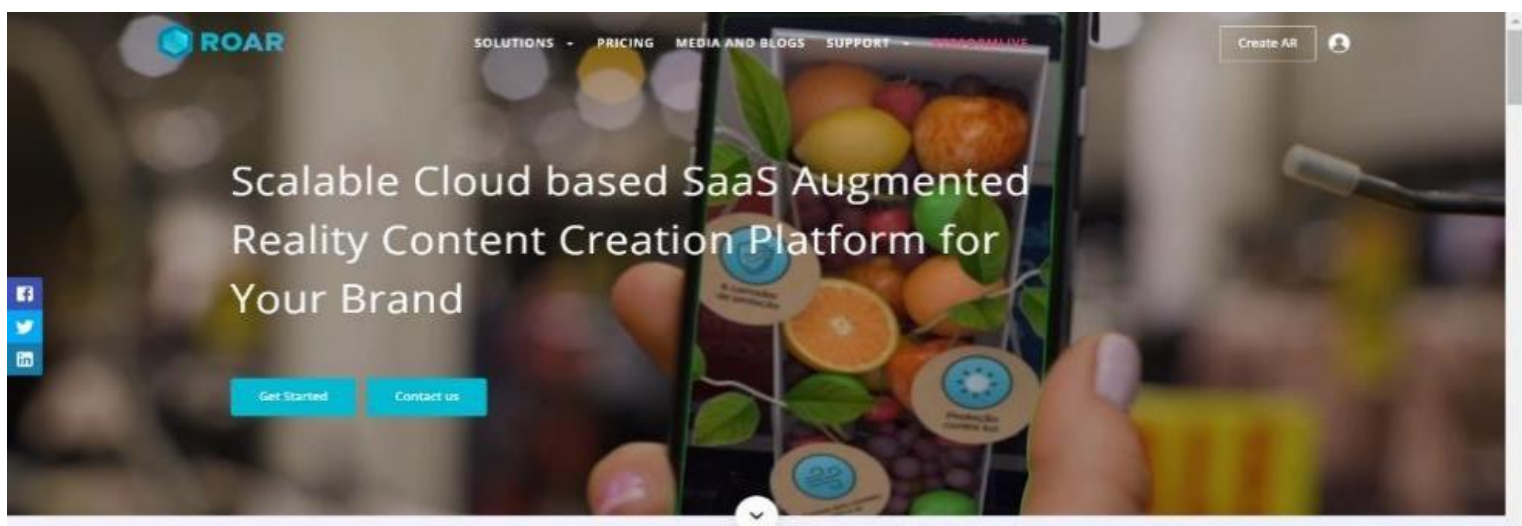

Brands that ROAR

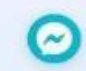

Figure 2: ROAR website

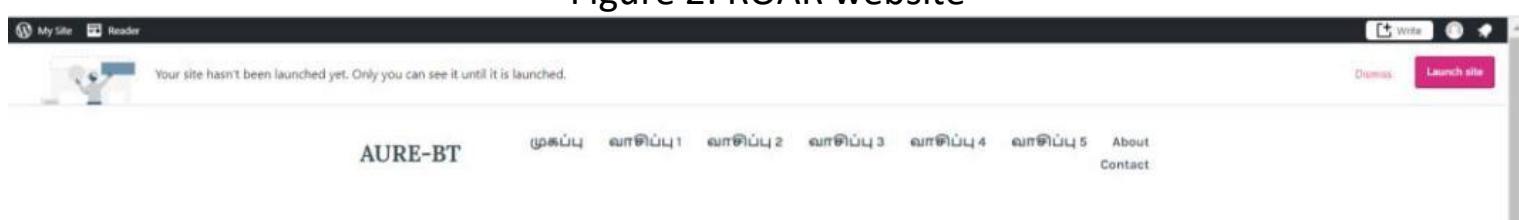

முகப்பு

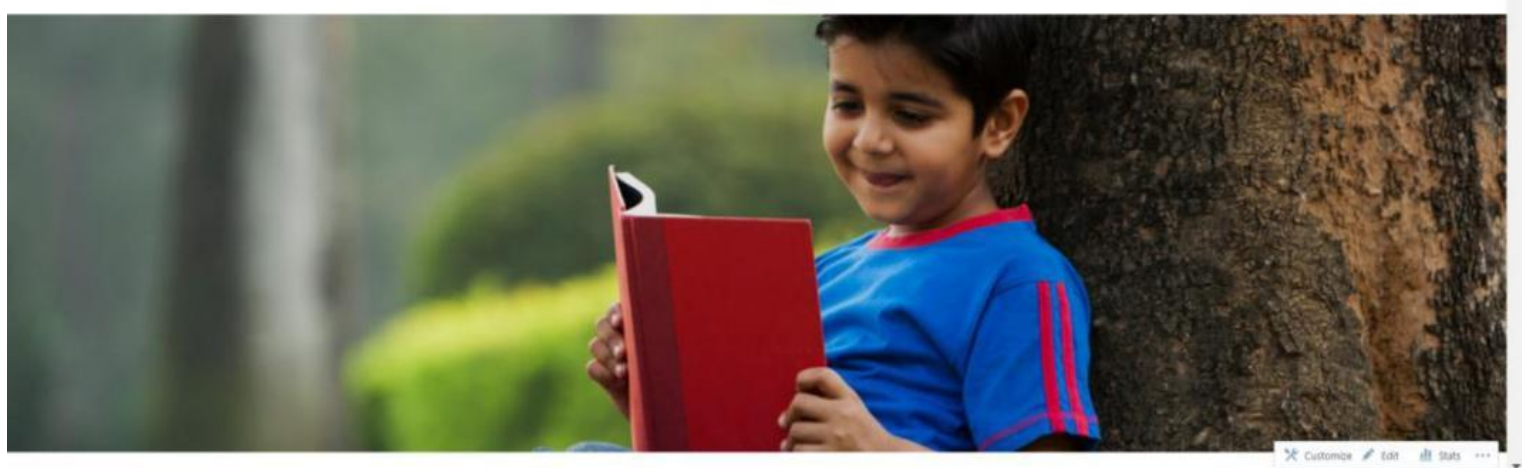

Figure 3: Home page of AuRa-BT

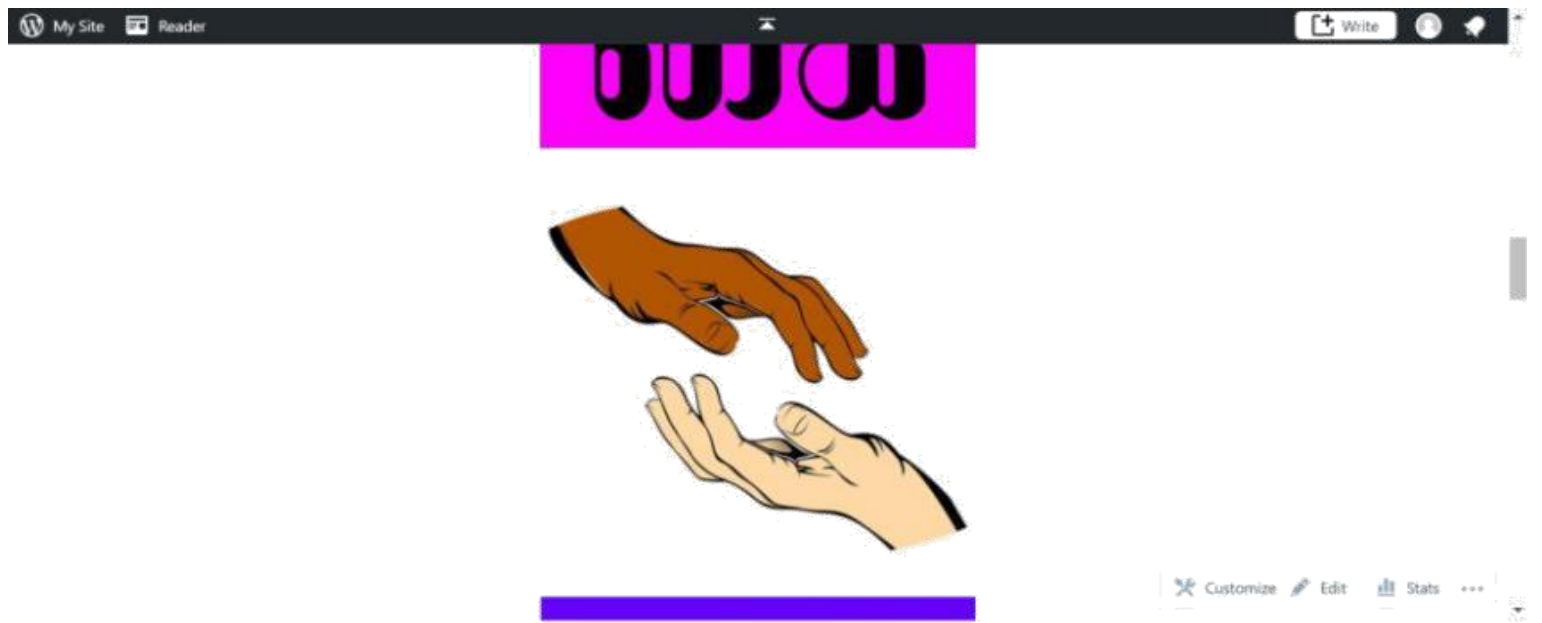

Figure 4: Example words and pictures that students need to recall through ROAR application 

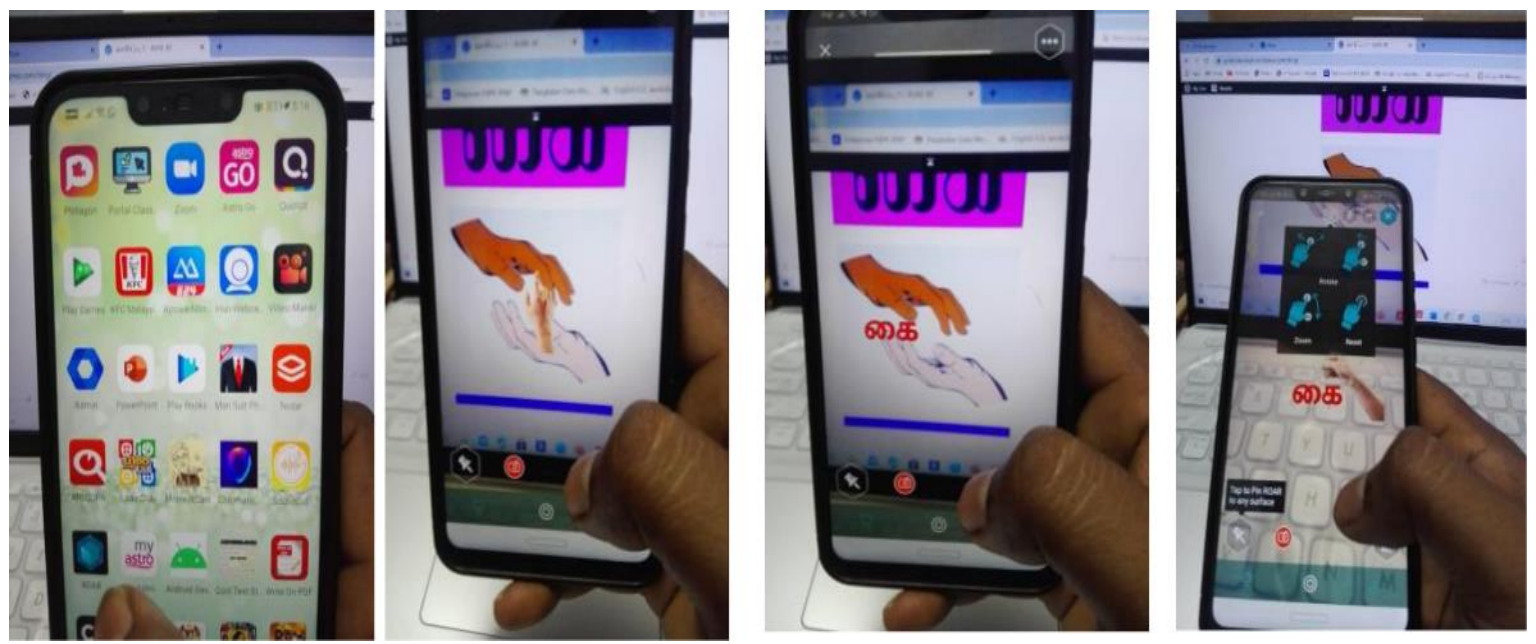

Figure 5: Example of a 3-D shape video included with audio calling words such that will Get out when the pupil scans at the picture words

Data collection at the early stage was done with some teachers in schools to familiarize them with the aim and features of AuRa-BT and to identify student weaknesses in reading the Tamil language. This will help the module developer plan, design, and develop a module to suit their needs. For content validation, a few Tamil language teachers were given a checklist to check and review the content of AuRa-BT regarding its usability. The list helps teachers to review based on the checklist according to technical, language and content. Thus, Tamil language teachers can give reviews about the weaknesses and strengths of AuRa-BT to facilitate researchers make final improvements. The checklist content for this research includes the following: Part A: Respondents Details, Part B: Application of Instructional Design (ID), Part C: Usability, Part D: Comments / Suggestions. The usability test assessed reading skills before and after using AuRa-BT with the Whizzer quiz game. The purpose is to identify the level of reading skills and usefulness of AuRa-BT. According to Idris (2010), all research involves data collection. Data refers to information obtained about the topic of the study.

\section{Findings and Discussion}

Before implementing the module for end-users in a real authentic environment, the usability test of the AuRa-BT module was conducted with Tamil language teachers through Google Form. The purpose of the usability test is to make improvements to the AuRa-BT module. Findings show how the application of minimalist theory as a component in the Udin model during design, development and implementation of AuRa-BT is perceived-in Table 1. It shows all $8(100 \%)$ respondents agree to all items. All $8(100 \%)$ Tamil language teachers agreed to items 1-6 about Minimalist theory. 
Table 1: Evaluation results application theory minimalist in components of the Udin Model

Bil Item $\quad$ Yes No.

1. students are motivated to read Tamil words through AuRa-BT $8(100 \%) 0(0 \%)$

2. students can read Tamil words in AuRa-BT $8(100 \%) 0(0 \%)$

3. Tamil words in AuRa-BT conform to year 4 curriculum $8(100 \%) 0(0 \%)$

4. AuRa-BT is easily operated in the teaching and learning process $8(100 \%) 0(0 \%)$

5. AuRa-BT can be use by students from any level who have $8(100 \%) 0(0 \%)$ problems with Tamil reading skills

6. instructions on how to operate the AURA-BT are given clearly $8(100 \%) 0(0 \%)$

Usability from the technical and content aspects shows that Tamil language teachers agree that AuRa-BT is usable. Table 2 indicates that $8(100 \%)$ of the Tamil language teachers agree on items $10,11,12,13$ dan 14 of Part $C$, which is the usability of the content and technicalities. In the $D$ section, which is the open-ended section, the respondents commented that AuRa-BT is usable to increase reading skills to learn words in Tamil even in preschool.

Table 2: Usability technical and content AuRa -BT

\begin{tabular}{|c|c|c|c|}
\hline Bil & Item & Yes & No. \\
\hline 10. & Does the color of the writing used match the backgrour & ? (100\%) & $0(0 \%)$ \\
\hline 11. & Is the AuRa-BT blog menu, easy to use? & $8(100 \%)$ & $0(0 \%)$ \\
\hline 12. & Is the type of writing that AuRa-BT uses easy to read? & $8(100 \%)$ & $0(0 \%)$ \\
\hline 13. & Is the display used by AuRa-BT attractive? & $8(100 \%)$ & $0(0 \%)$ \\
\hline 14. & Is the delivery of AuRa-BT content orderly? & $8(100 \%)$ & $0(0 \%)$ \\
\hline
\end{tabular}

Usability test also shows that AuRa-BT help increase skills to read Tamil, as shown in Table 3 and Figure 6. Online quizzes were conducted before and after using Aura-BT. Students were able to read one letter, two letters, three letters, four letters and five letter-words in the Tamil language through game quizwhizzer. The total of letters read by the pupil is 50 .

Table 3: Analysis of Pre and Post Test

\begin{tabular}{|c|c|c|c|c|c|c|}
\hline \multirow[b]{4}{*}{ Gred } & \multirow[b]{4}{*}{ Statement } & \multirow[b]{4}{*}{ Percent \% } & \multicolumn{2}{|l|}{ Pre } & \multicolumn{2}{|l|}{ Post } \\
\hline & & & \multicolumn{4}{|l|}{ NUMBER } \\
\hline & & & \multicolumn{2}{|l|}{ OF } & \multicolumn{2}{|c|}{ NUMBER OF } \\
\hline & & & STUDENTS & & STUDENTS & $\%$ \\
\hline $\bar{A}$ & Excelent & $80-100$ & 0 & 0 & 40 & 80 \\
\hline B & Good & $60-79$ & 0 & 0 & 10 & 20 \\
\hline C & Simple & $40-59$ & 12 & 24 & 0 & 0 \\
\hline D & Weak & $20-39$ & 18 & 36 & 0 & 0 \\
\hline $\mathbf{E}$ & Very Weak & 20 & 20 & 40 & 0 & 0 \\
\hline
\end{tabular}

Data obtained from the pre and post-test after using AuRa-BT module shows a total of 40 students (80\%) got are position as excellent and a total of 10 students $(20 \%)$ were positioned as good. In conclusion, 50 respondents $(100 \%)$ have succeeded in increasing improvement. This shows that module AuRa-BT used by researchers helps students to master skills to read Tamil words. 


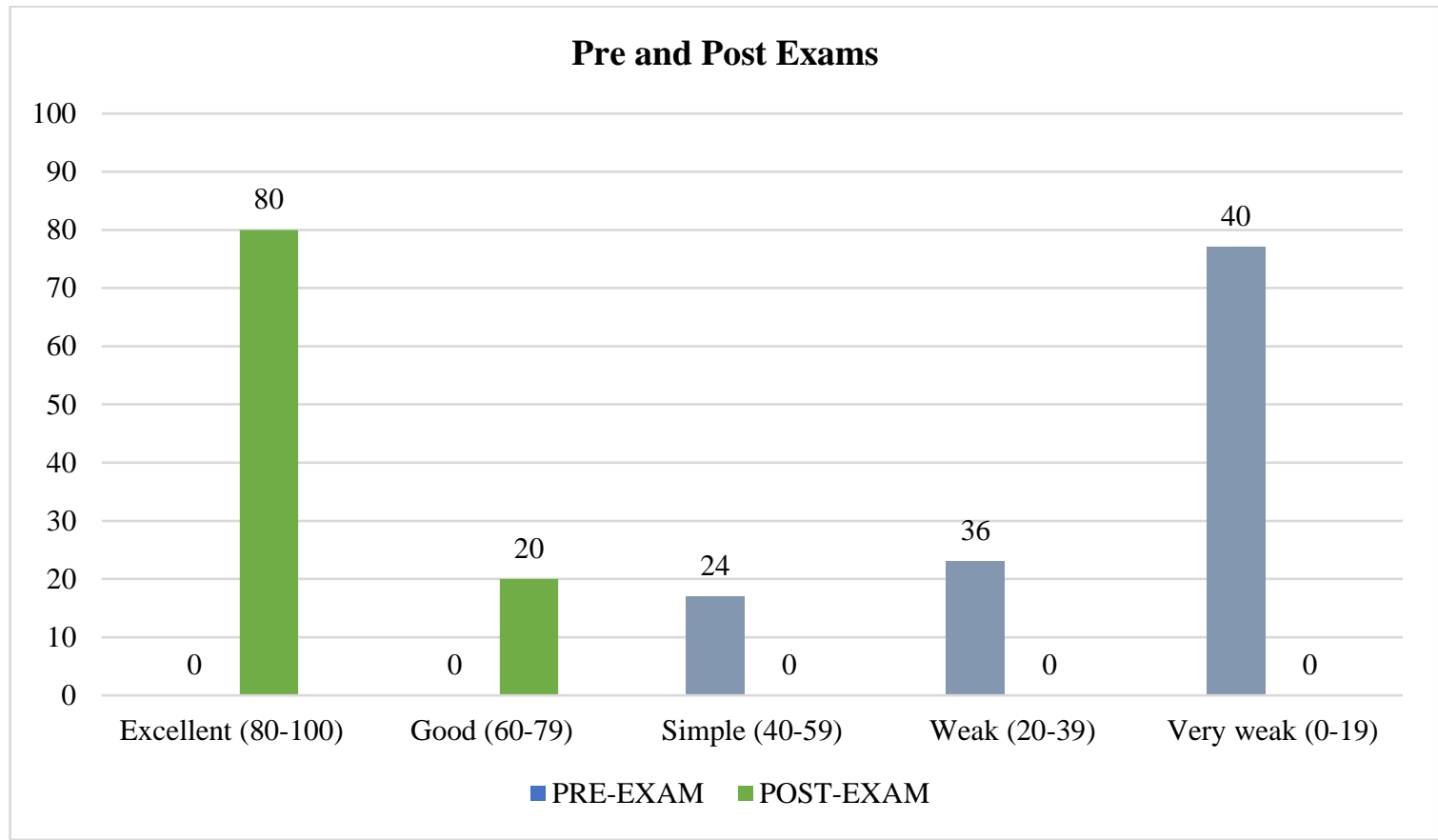

Figure 6: Analysis The test Pre and Post

Next, usefulness AuRa -BT module from aspect easy learn shows $12 \%$ (6 students) of respondents agreed, $88 \%$ (44 students) of respondents strongly agreed. Some respondents stated agree and strongly agreed about the module that helps easy learn Tamil language reading. This show response positive in circles responded against module AuRa -BT. The usefulness module from the aspect of easy usage showing $2 \%$ ( 1 student) of respondents agreed and as many as $98 \%$ (49 students) of respondents strongly agreed. All respondents of the research, that is, $100 \%$ (50 students) rated strongly agreed with module items. This AuRa -BT friendly-users, provided steps to facilitate reading skills, as a result, it was not difficult to use the module AuRa-BT. The analysis from these results, the responded interest against use module This AuRa -BT, found the majority of the respondents gave a positive response. Among the most important factors of the use of AR in reading Tamil words in AuRa -BT is to encourage students to generate their income. When observed through this questionnaire, everyone responded positively to their assessment. It can be seen no responden expressed slightly disagree, disagreement and strongly disagreed. When analysis of question investigates all respondents about usefulness and effectiveness AuRa -BT, majority indicated that the use of AR increases skills read Tamil words can attract interest and facilitate understanding on Tamil words. The use of AR cause from facing a combination of 3D video, music background back, 2D picture, interesting and appropriate sound and so on. The findings from the assessment on the use of this AuRa -BT Module answered 3 question of the study: What are the reading skills of Tamil for Year 4 Pupils after implementation from module AuRa -BT with aspect easy usage? 
Table 4: Analysis Question Investigate Usefulness of the AuRa -BT Module

\begin{tabular}{|c|c|c|c|c|c|c|}
\hline $\begin{array}{l}\mathrm{BI} \\
\mathrm{L}\end{array}$ & $\begin{array}{l}\text { SCALE } \\
\text { CRITERIA }\end{array}$ & $\begin{array}{l}\text { STRONG } \\
\text { LY } \\
\text { DISAGRE } \\
\text { E } \\
\text { (SD) } \\
1\end{array}$ & $\begin{array}{l}\text { DISAGRE } \\
\text { E } \\
\text { (D) } \\
2\end{array}$ & $\begin{array}{l}\text { SLIGHTLY } \\
\text { DISAGRE } \\
\text { E } \\
\text { (SLD) } \\
3\end{array}$ & $\begin{array}{l}\text { AGRE } \\
\text { E } \\
\text { (A) } \\
4\end{array}$ & $\begin{array}{l}\text { STRONG } \\
\text { LY } \\
\text { AGREE } \\
\text { (SA) } \\
5\end{array}$ \\
\hline \multicolumn{7}{|c|}{ AURA-BT MODULE } \\
\hline 1. & $\begin{array}{l}\text { Provide motivation to learn } \\
\text { Tamil words }\end{array}$ & 0 & 0 & 0 & $4(8 \%)$ & $46(92 \%)$ \\
\hline 2. & $\begin{array}{l}\text { Read one-five letters of Tamil } \\
\text { words }\end{array}$ & 0 & 0 & 0 & $4(8 \%)$ & $46(92 \%)$ \\
\hline 3. & $\begin{array}{l}\text { See new environments that } \\
\text { look at the real world through } \\
\text { a computer screen (3D) }\end{array}$ & 0 & 0 & 0 & $4(8 \%)$ & $46(92 \%)$ \\
\hline 4. & $\begin{array}{l}\text { Helps me master reading skills } \\
\text { in more depth }\end{array}$ & 0 & 0 & 0 & $\begin{array}{l}6(12 \\
\%)\end{array}$ & $44(88 \%)$ \\
\hline 5. & $\begin{array}{l}\text { Learn quickly by doing self - } \\
\text { reading }\end{array}$ & 0 & 0 & 0 & $4(8 \%)$ & $46(92 \%)$ \\
\hline \multicolumn{7}{|c|}{ USEFULNESS OF AURA-BT MODULE (Easy Learning Students) } \\
\hline 6. & $\begin{array}{l}\text { This AuRa-BT module helps me } \\
\text { learn easily }\end{array}$ & 0 & 0 & 0 & $\begin{array}{l}6(12 \\
\%)\end{array}$ & $44(88 \%)$ \\
\hline 7. & $\begin{array}{l}\text { This AuRa-BT module is very } \\
\text { easy for me to read }\end{array}$ & 0 & 0 & 0 & $2(4 \%)$ & $48(96 \%)$ \\
\hline 8. & $\begin{array}{l}\text { This AuRa-BT module helps me } \\
\text { become more motivated }\end{array}$ & 0 & 0 & 0 & $4(8 \%)$ & $46(92 \%)$ \\
\hline 9. & $\begin{array}{l}\text { This AuRa-BT module } \\
\text { increases curiosity }\end{array}$ & 0 & 0 & 0 & $\begin{array}{l}6(12 \\
\%)\end{array}$ & $44(88 \%)$ \\
\hline 10. & $\begin{array}{l}\text { This AuRa-BT module helps me } \\
\text { think imaginatively }\end{array}$ & 0 & 0 & 0 & $3(6 \%)$ & $47(94 \%)$ \\
\hline \multicolumn{7}{|c|}{ USEFULNESS OF AURA-BT MODULE (Student Easy to Use) } \\
\hline 11. & $\begin{array}{l}\text { This AuRa-BT module is easy to } \\
\text { use. }\end{array}$ & 0 & 0 & 0 & $1(2 \%)$ & 49(98\%) \\
\hline 12. & $\begin{array}{l}\text { This AuRa-BT module is not } \\
\text { complicated to use. }\end{array}$ & 0 & 0 & 0 & $1(2 \%)$ & $49(98 \%)$ \\
\hline 13. & $\begin{array}{l}\text { This AuRa-BT module is user } \\
\text { friendly. }\end{array}$ & 0 & 0 & 0 & 0 & 0 \\
\hline 14. & $\begin{array}{l}\text { This AuRa-BT module provides } \\
\text { simple steps to facilitate } \\
\text { reading skills }\end{array}$ & 0 & 0 & 0 & 0 & 0 \\
\hline 15. & $\begin{array}{l}\text { It is not difficult to use this } \\
\text { AuRa-BT module. }\end{array}$ & 0 & 0 & 0 & 0 & 0 \\
\hline
\end{tabular}


DEVELOPMENT

Vol. 11, No. 1, 2022, E-ISSN: 2226-6348 @ 2022 HRMARS

\section{Implication's Research}

This study is one effort that helps students read words language of Tamil with ease. This is because teaching and learning AR-based has the potential to bring virtual education to the real world. In short, AR refers to real-world concepts intertwined with the virtual world. It can change the learning environment by inserting real environment to virtual information that includes variation graphics, video, audio. Interestingly, this kit continues with an educational agenda-driven digital-based DL learning (deep learning). It is also closely related to MOE 's intentions in the Education Development Plan (PPPM) 2013-2025, producing superior human capital through targeted goals.

The use of AURA-BT can help assist the learning process inside and out-of-class. Students do not, acquire a material of book text, but they can access page web concerned. This kit includes elements, animations, games and graphics that allow learning to be implemented in more fun. Moreover, this kit can develop student potential in surfing information for solution learning. The use of ICT in innovation can enhance the learning process even more fun, easy, fast, and accessible anywhere and anytime and save costs. The use of AR in session teaching can give one new dimension in education because of its characteristics; its flexibility allows accessibility and access at any time through everywhere. AURA-BT can create an environment of interesting and fun learning. Sophistication technology gives visualization experience to students so that they are more excited in knowledge because of the interesting media used. Clearly, the use of AURA-BT can attract student interest for deeper reading.

Combining the AURA-BT module with the Roar (AR) application is used in the education area to realize an engaging and fun learning environment for students. Advanced technology gives a visual experience to the pupil that makes them excited for learning. In addition, AURA-BT emphasizes learning-based game approach. According to Piaget (1962), play gives opportunities to children to express thoughts, feelings, and emotions. (Add about play here or line before) In short, AURA-BT was produced by the researcher to provide opportunities for the students to learn solving various problems (cognitive, manipulative, social) that contribute to progress intellect.

Researchers produced AURA-BT to reduce operating costs, i.e., students do not need to buy AR (ROAR) applications. Students only need to download the ROAR app on their smartphone. Next, students need to scan picture words on page web on their smartphone to learn pronunciation of Tamil words. Students will then listen to audio and video on their smartphones. Students will learn to spell syllables via audio are removed in a way AR technology. Students will be writing of the language Tamil, mention words language Tamil, and the end once read the words. This reduces operating costs and saves time as it only uses one application to access the audio or video with the presence of an internet line.

\section{Recommendations}

As a proposal of researchers after application the use of AURA-BT among students, have a huge impact in increase reading skills more effectively. Some suggestions can be taken from the conclusion studies that have been run. Suggestions submitted as suggestions to: 
DEVELOPMENT

Vol. 11, No. 1, 2022, E-ISSN: 2226-6348 @ 2022 HRMARS

\section{Ministry of Education Malaysia (Moe)}

AURA-BT module developed this made as one module reading in DELIMA KPM to help each student read Tamil words. This AURA-BT can be an Education Malaysia material so that students and teachers can use this AURA-BT for reading words. It also gives opportunities to students improve their reading skills

\section{Research Next}

1. The study also expects research continued with improvement to the field of Education.

2. Expand the implementation of AURA-BT at the level of the Ministry of Education Malaysia or schools.

3. Effectiveness of AURA-BT learning method according to augmented Reality or Virtual Reality learning style.

4. Add more module content AURA-BT learning that involves learning in Virtual Reality.

5. Develop mobile application modules that support the development of AURA-BT modules.

\section{Conclusion}

The use of AR nowadays is an exciting parallel with the progress of education. Therefore, teachers need to have knowledge in the field of $A R$, especially in teaching. Results of the study show that the implementation of AuRa -BT as material help increase read skill-and has positive effect in learning Tamil. The positive impact of this can be known through pre and post exam, question surveys, and lists checked with students and teachers. A total of 50 Tamil students and teachers have given positive responses against using This AuRa-BT. This research can also see that AuRa -BT can be one of the teaching aids that can help improve reading skills in addition to attract students' interest and motivation to succeed. Thus, the researcher also hopes teachers, administrators, school, JPN, plays their respective roles to make sure education of our country continues at an excellent level. The implementation of AuRa-BT among students has a huge impact in increasing skills effective reading. This AuRa-BT can be made as AR Education materials in Pomegranate Ministry of Education Malaysia. It also gives opportunities to increase students' reading skills.

The use of AuRa -BT for educational purposes, especially in schools, is still in its early stages. Various factors need to be considered in the success of this effort to ensure that the application developed meets the teaching and learning objectives that have been set. The UDin model is very beneficial and can be used by other researchers and developers to produce effective and more attractive educational applications in the future. In addition, the researcher would also like to give recommendations to all application or software developers in education. One of them is to emphasize the values aspect in each material to be produced. This aspect of values needs to be emphasized so that the materials developed can influence the psychology and behavior of consumers in a better direction. Therefore, the researcher developed the AuRa-BT using the UDin model because it emphasizes the value element in the instructional model in development. The development of AuRa-BT modules involves a lot of application of minimalist theory which allows students to independently start learning as soon as possible. The minimalism theory in AuRa-BT aims to compact a long description so that it is more compact and concise to make it easier for students to understand a piece of 
content. Despite the various limitations and constraints faced, it is hoped that all the issues reported can be given attention and improvement by researchers in the future.

\section{Acknowledgments}

We would like to convey our utmost appreciation to STEM Enculturation Research Centre, Faculty of Education, Universiti Kebangsaan Malaysia for grants Dana Pecutan, and GUP2020-020 and support to publish this journal publication. Special thanks to all researchers under the Personalized Education Research Group for their financial, intellectual, spiritual, and moral support.

\section{References}

Abdul Mutalib, N. (2017). Pembelajaran Abad 21 Bukan Sekadar Susun Kerusi dan Meja. Perlis: Percetakan Perlis (1990) Sdn. Bhd.

Abdul Razak, N. (2019). Sistem IQ NILAM Bantu Lahirkan Pembaca Berkualiti. Pendidik. https://www.pendidik.com.my/2019/01/08/sistem-iq-nilam-bantu-lahirkan-pembacaberkualiti/

Azuma, R. T. (1997). A Survey of Augmented Reality. Presence: Tele-operators and Virtual Environments, 6(4), 355-385.

Azuma, R. T., Baillot, Y., Behringer, R., Feiner, S., Julier, S., \& Maclntyre, B. (2001). Recent Advances in Augmented Reality. Journal of Computer Graphics and Applications, 2(6), 34-47.

Ganti, B. M. Z., \& Lubis, M. A. (2018). Pendekatan Augmented Reality (AR) dalam Pengajaran dan Pemudahcaraan (PdPc) Bahasa Arab di Malaysia [Paper presentation]. The $11^{\text {th }}$ International Workshop and Conference of Asean Studies in Liguistics, Islamic and Arabic Education, Social Sciences and Educational Technology, Asahan University, Indonesia.

Chehimi, F., Coulton, P., \& Edwards, R. (2007). Augmented Reality 3D Interactive Advertisements on Smartphones. Sixth International Conference on the Management of Mobile Business (ICMB 2007).

Chen, C. J. (2006). The design, development and evaluation of a virtual realitybased learning environment. Australian Journal of Educational Technology, 22(1), 39-63.

Dunser, A., \& Billinghurst, M. (2007). Human-Centered Development of an AR Handheld Display. Proceedings Mixed and Augmented Reality (pp. 177-180).

Din, R. (2020). Notes from the Chief Editor: On Universal Design and Agile Development. Journal of Personalized Learning, 3 (1), i -vii.

Din, R., Othman, N., Murat, N., Alias, M., Nasir, M. (2017a). Formative to summative in one go. Presented at: Holistic Learning Conference (Rahole); November 20-21; Kuala Lumpur.

Din, R., Othman, N., Murat, N., Alias, M., Nasir, M. (2017b). Reflection in a blog: scaffolding to formative and summative assessment. 2017. Presented at: Holistic Learning Conference (Rahole); November 20-21; Kuala Lumpur.

Din, R. (2017). Asas Pendidikan dan Kejurulatihan ICT: Integrasi Teori Media, Teknologi dan Reka Bentuk Pembelajaran. Bangi: Penerbit UKM.

Din, R. (2016). Notes from the Chief Editor on Designing Personalized Learning. Journal of Personalized Learning, 2 (1), i -iii.

Din, R. (2014). Pembinaan dan Permodelan Sistem Pengajaran. Bangi: Penerbit UKM. 
Din, R. (2010). Development and validation of an integrated meaningful hybrid Etraining (IMeT) for computer science: Theoretical-empirical based design and development approach. (Doctoral thesis, University National Malaysia). Retrieved from http://myto.upm.edu.my/find/Record/ukmvital-3518.

Din, R. (2004). Pembinaan sistem e-Bincang menggunakan rangkaian jauh. (Technical report, Universiti Kebangsaan Malaysia).

Din, R. (2001). Pembinaan sistem persidangan berkomputer: Sidangkom. (Master thesis, Universiti Kebangsaan Malaysia). Retrieved from http://myto.upm.edu.my/find/Record/ukm..b13140607.

Jantakoon, T., Wannapiroon, P., \& Nilsook, P. (2019) Virtual Immersive Learning Environments (VILEs) Based on Digital Storytelling to Enhance Deeper Learning for Undergraduate Students. Higher Education Studies, 9 (1), 144-150.

Jenal, M. Z. (2017). Persepsi Pelajar Terhadap Penggunaan Sistem Rangkaian Media Sosial Telegram. Sebagai Alat Pembelajaran Modul Matematik: Satu Tinjauan Kes Di Kolej Komuniti Kuala Langat. E-Proceedings National Innovation and Invention Competition Through Exhibition iCompEx17 Academic Paper (pp. 1-9).

Karim, N. S. (1989). Beberapa Persoalan Sosiolinguistik Melayu. Kuala Lumpur: Dewan Bahasa dan Pustaka.

Lam, M. C., Tee, H. K., Nizam, S. S. M., Che Hashim, N., Suwadi, N. A., Tan, S. Y., \& Liew, S. Y. (2020). Interactive Augmented Reality with Natural Action for Chemistry Experiment Learning. TEM Journal, 9(1), 351-360.

Zaki, M. A. Z. (2014). Penggunaan Bahan Tiga Dimensi (3D) Untuk Meningkatkan Kemahiran Berfikir Aras Tinggi dalam Subjek Kajian Tempatan Bagi Murid Tahun 5 [Paper presentation]. Prosiding Seminar Penyelidikan Tindakan Pelajar 2014. Institut Pendidikan Guru Kampus IImu Khas, Kuala Lumpur, Malaysia.

Muniandy, T., \& Desen, T. (2015). Persepsi Terhadap Penggunaan ICT dalam Pengajaran Pendidikan Jasmani dan Pendidikan Kesihatan dalam Kalangan Guru PJPK di Kedah. Prosiding Seminar Penyelidikan Pendidikan Kebangsaan (SPPK)(pp. 511-522).

Saeed, S., \& Zyngier, D. (2012). How Motivation Influences Student Engagement: A Qualitative Case Study. Journal of Education and Learning, 1(2), 252-267.

Siltanen, S. (2012). Theory and applications of marker-based augmented reality: Licentiate thesis. VTT Technical Research Centre of Finland, Finland.

Stapleton, P. J., Cooney, A. M., \& Hix Jr, W. M (1996.). Environmental Management System: An Implementation Guide for Small and Medium-Sized Organization. Michigan: NSF International.

Vargavan, S. N., \& Yunus, F. (2021). Penggunaan augmented reality (AR) untuk meningkatkan kemahiran membaca perkataan bahasallnggeris kanak-kanak prasekolah. International Journal of Education and Pedagogy, 3 (1), 156-172.

Yusof, A. A., Adnan, M. A. H., Kamal, M. N. N., Kamal, M. A., \& Ahmad, M. K. (2019). Education 4.0 Immersive Learning with Spherical Videos $\left(360^{\circ}\right)$ and Virtual Reality (VR) Experiences. Proceedings: International Invention, Innovative \& Creative (InIIC) Conference, Series 2 (pp. 52-60).

Yusof, M. N. M., \& Tahir, Z. (2017). Kepentingan penggunaan media sosial teknologi maklumat dalam pendidikan IPTA. eBangi - Journal of Social Sciences and Humanities 12 (3), 1-10. 